\title{
Consortium for research and innovation in aerospace in Quebec, Canada - a reference model for the Brazilian aerospace industry
}

\author{
Fabiano Armellini", Paulo Carlos Kaminski ${ }^{a}$, Catherine Beaudry ${ }^{b}$ \\ aEscola Politécnica da Universidade de São Paulo \\ bécole Polytechnique de Montréal \\ e-mails: farmellini@usp.br; pckamins@usp.br; catherine.beaudry@polymtl.ca
}

\begin{abstract}
The theory of systems of innovation stresses the importance of knowledge and technology flows among people, firms and institutions for the development of a productive innovation ecosystem in a local region. One of the most important recommendations from specialists in the subject is to set local policies that benefit the interaction between enterprises and science \& technology institutes (STI). Within this context, this paper aims to present and analyze the framework adopted by the Province of Quebec, in Canada, to enhance the cooperation between local enterprises and STIs in the development of precompetitive technologies in the aerospace sector, through a consortium named CRIAQ (Consortium de recherche et d'innovation en aérospatiale au Québec), and to analyze its applicability to the Brazilian aerospace industry.
\end{abstract}

Keywords: systems of innovation, triple helix, pre-competitive technologies, research \& development (R\&D), university-enterprise collaboration.

\section{Introduction}

The theory of systems of innovation approaches the way governments see and study the innovation process. It states that the flow of knowledge, technologies and information among institutions is critical to the success of innovation in local firms of a given region or country.

The concept of systems of innovation is a theme that has been present in the specialized literature since the mid1980's, when Lundvall (1985), Freeman $(1987 ; 1988)$ and Nelson (1988) published a series of studies whose proposal is to analyze how the local environment contributes for the encouragement of the innovation in firms of a given geographic location. More precisely, Freeman (1987; 1988) devotes himself to the study of the Japanese system of innovation; Nelson (1988), in his turn, takes the USA as the object of his studies; as for Lundvall (1985), he approaches the theme under a more theoretical point of view, adopting the evolutionary econometric model to raise the hypotheses that systems of innovation evolve from clientsupplier interactions, using as background the economic transformations that took place in Europe to illustrate the concept.

Later on, these pioneers along with other scholars performed similar analyses within different contexts and with different approaches (e.g. LUNDVALL, 1992; NELSON, 1993; WONG, 1999; ANDERSEN, 1999). All these studies contributed for the formulation of a concise conceptual model that suggests that firms do not innovate alone; on the contrary, they depend on a complex institutional framework and strong ties with several other actors to innovate. When approached generally, this theory is named "systems of innovation" (SI); however, when applied to specific regions, it is also known as "regional systems of innovation" (RSI) or "national systems of innovation" (NSI) when it analyses the theme within the economy of a whole country. Nowadays, the SI theoretical model is considered a very mature one, properly verified in the scientific and specialized literature, as can be noticed in various works of explanatory nature on the subjects (e.g. DOSI, et al., 1988; OECD, 1997; LASTRES; CASSIOLATO; ARROIO, 2005).

Although this theory is relatively recent, the idea is much older. As Freeman (1995) admits, back in 1841 Friderich List created the concept of a "national system of political economy" to explain how Germany could overcome the United Kingdom in industrial organization at this time, and had proposed public policies for the local support of the industrial development of non-industrialized regions. Therefore, modern SI theory contains conceptual elements that predate the model, whose main contribution is an integrated vision.

Another preexisting idea that is incorporated to the SI model is the triple helix concept, which is a term already used in the 1960's by Sábato and Botana (1968). What the 
triple helix advocates is the necessity of interaction between the productive structure (firms), the technological-scientific infrastructure (universities and other science and technology institutes - STI), the first as the agent that promotes innovation in the market and the latter as the agent that generates and holds the scientific and technical knowledge required for such innovations. Since these agents differ (and even diverge, sometimes) in their goals and methods, they do not normally interact with the required intensity. For that reason, the aid of a third agent, the government, is required to serve as a catalyst for the STI-enterprise relationship, by means of incentive policies, investments in local research and development (R\&D) infrastructure and, ultimately, as the purchaser of cutting-edge technology, as it often happens in the case of technology development contracts in strategic sectors such as defense, aerospace and energy. Figure 1 represents these interactions as a triangle whose vertices are the three agents, namely: firms, government and STI. The sides of the triangle represent the flows of information, knowledge and resources that are critical for the proper functioning of the local SI, according to this theory.

Another recent concept within the innovation literature is the open innovation model, which has been gradually raising interest both in the academy (DAHLANDER; GANN, 2010) and in the industry (CHESBROUGH, 2003). In relation to the systems of innovation model, open innovation is more recent and is still at the stage of conceptualization and exploratory research (HUIZINGH, 2011). Open innovation advocates, from the perspective of companies, that they can and should combine internal and external knowledge, and internal and external paths to market, as they look to advance in their technology (CHESBROUGH, 2003).
A study from De Jong et al. (2008), which aims to analyze the implication of open innovation for governmental policies on research, development and innovation (RD\&I), shows that the theories of open innovation and systems of innovation are in harmony with each other. To prove that, they draw a parallel between excerpts from scholars specialized in each one of the research topics, in order to show the proximity between them, as reproduced in Table 1 .

In fact, one can notice in this table that both theories dealt with the same technical-economic phenomenon, though from different perspectives: open innovation analyses flows of knowledge from the perspective of the firm, while systems of innovation study the same flows, but from the perspective of public policy makers and governments.

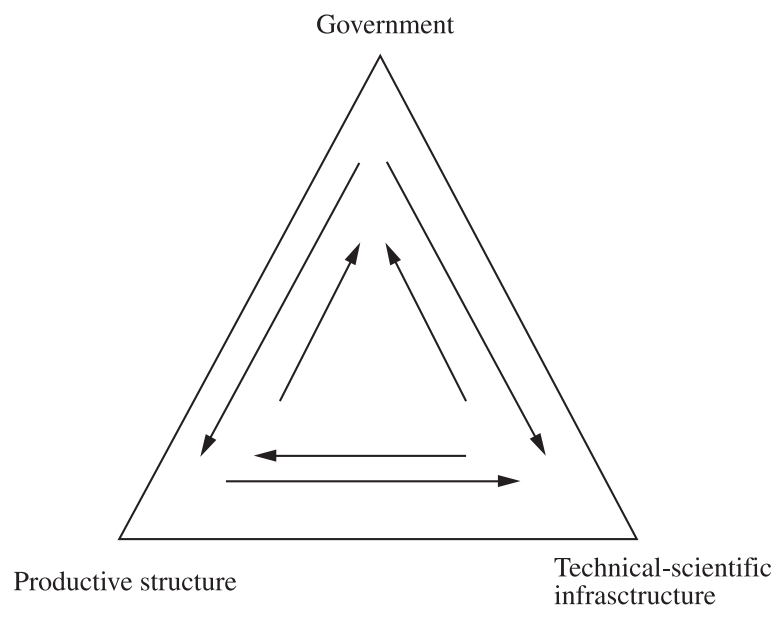

Figure 1. Triple helix. Source: adapted from Sábato and Botana (1968).

Table 1. Similarities between the open innovation and systems of innovation literatures.

\begin{tabular}{|c|c|}
\hline Open innovation & Systems of innovation \\
\hline $\begin{array}{l}\text { Enterprises obtain better results if they open up their innovation } \\
\text { processes, i.e. involve the world outside. }\end{array}$ & $\begin{array}{l}\text { Innovation is the result of complex and intensive interactions between } \\
\text { various actors. }\end{array}$ \\
\hline $\begin{array}{l}\text { Innovation is no longer the domain of the internal R\&D department; } \\
\text { traditional stage-gate models provide an incomplete picture of how } \\
\text { innovation should be organized. }\end{array}$ & $\begin{array}{l}\text { The linear model in which knowledge-related activities are divided in } \\
\text { supply and demand does not hold any longer. }\end{array}$ \\
\hline $\begin{array}{l}\text { Enterprises can benefit from purposive inflows and outflows of } \\
\text { knowledge. Knowledge spillovers offer opportunities and are not } \\
\text { just a threat. }\end{array}$ & $\begin{array}{l}r \text { the functioning of the innovation } \\
\text { e. }\end{array}$ \\
\hline $\begin{array}{l}\text { Enterprises need both internal innovation competences (other than } \\
\text { R\&D) and competences to connect with external parties in order to } \\
\text { be successful. }\end{array}$ & $\begin{array}{l}\text { nnovation systems can be hampered by capability } \\
\text { s. }\end{array}$ \\
\hline $\begin{array}{l}\text { As enterprises increasingly depend on external sources, infrastructural } \\
\text { arrangements (e.g. IPR) and other framework conditions become } \\
\text { more important. }\end{array}$ & $\begin{array}{l}\text { The functioning of innovation systems can be hampered by institutional } \\
\text { and framework failures. }\end{array}$ \\
\hline $\begin{array}{l}\text { Increased mobility of labor and presence of a trained labor force are } \\
\text { important trends that eroded the closed innovation model. }\end{array}$ & $\begin{array}{l}\text { Human and social capital provide the oil necessary for lubricating the } \\
\text { innovation system. }\end{array}$ \\
\hline $\begin{array}{l}\text { If the innovating enterprise cannot internally benefit from its } \\
\text { innovations, maybe others can. }\end{array}$ & $\begin{array}{l}\text { The social benefits of innovation exceed those of the individual } \\
\text { innovating actors. }\end{array}$ \\
\hline
\end{tabular}

Source: De Jong et al. (2008). 
Since both theories converge in many aspects, the OECD (2008) has recently published a study on open innovation that aims, among other goals, to show empirical evidence of this convergence.

\section{Objective and structure of the paper}

Within the theoretical context presented in section 1 , this paper aims to present a case of successful implementation of a governmental program for enabling STI-firm cooperation, adopted by the aerospace industry in the Province of Quebec, in Canada, and to analyze its applicability to the Brazilian industry. The object of study in the paper is the CRIAQ (Consortium de recherche et d'innovation en aérospatiale au Québec*), a consortium of research and innovation dedicated to the establishment of collaborative links between companies and STIs in the local aerospace industry, created by an academic initiative and financed by the Province government.

This paper is part of a collaborative research project between Escola Politécnica da Universidade de São Paulo (Brazil) and École Polytechnique de Montréal (Canada) whose goal is to search and compare evidence of open innovation practices in the aerospace industries in two different aerospace poles: the Province of Quebec in Canada and the State of São Paulo in Brazil.

Given the context of the work, the remaining of this paper is structured in the following fashion: section 3 presents CRIAQ and its local context; section 4 analyzes the applicability of such a model in the Brazilian aerospace industry context; finally, section 5 draws some conclusions from this analysis and points out implications for future studies on the theme.

\section{CRIAQ - Consortium de recherche et d'innovation en aérospatiale au Québec}

CRIAQ is a non-profit consortium composed by governmental agents, universities and aerospace companies residing in the Province of Quebec, in Canada, whose goal is "[...] to promote and perform collaborative pre-competitive industry research projects primarily at universities." (FORTIN, 2010, p. 2).

\subsection{CRIAQ's history}

The consortium originated in the year 2000, when Université de Sherbrooke professors Jean Nicolas and François Charron publish a paper dealing with the scientific, technological and social importance of a consortium dedicated for promoting research and innovation in the aerospace industry of Quebec, one of the most important economical segments of the Province (FORTIN, 2010). In the following year, the consortium became reality by the

* Consortium for Research and Innovation in Aerospace in Quebec. accession and engagement of agents in the three vertices of the triple helix.

Present from its inception, the consortium counts on the participation of six aerospace companies, including all four local industry prime contractors (namely: Bell Helicopter Textron, Bombardier Aéronautique, CAE and Pratt \& Whitney Canada), and two other important equipment suppliers: CMC Életronique and EMS Technologies (FORTIN, 2010).

Regarding the STIs, the consortium counts on the support from all Quebec universities and the CTFA (Centre des Technologies de Fabrication en Aérospatiale), the latter supported and financed by the federal government (FORTIN, 2010), all present since the creation of CRIAQ.

For the funding of projects of the consortium, participating companies have committed themselves to cover $25 \%$ of all research expenses, the remaining $75 \%$ to be financed by Quebec governmental funds. In the period from 2001 to 2006 , the first round of projects was put in place funded by a total budget of CAN\$ 6.5 million in grants, from public and private contributions; 13 collaborative projects were funded (FORTIN, 2010).

In 2006, CRIAQ was cited in an official document as a strategic axis of the government of Quebec for promoting innovation in the local aerospace industry (CANADA, 2006). For the occasion, the Provincial government committed additional CAN\$ 8.6 million for research up to the year 2010 (FORTIN, 2010).

In 2007, CRIAQ established its first international cooperation agreement with India for a research project on a film cooling technology for turbine airfoils, setting up a new model of collaboration for the consortium (CRIAQ, 2010).

At the end of 2010, the consortium counted 42 member companies, 15 STIs, in addition to the institutional support of the government and from industry associations (CRIAQ, 2010). An important highlight is the significant participation of small and medium enterprises (SME) in the consortium: in the 42 industry members, 27 are SMEs (CRIAQ, 2010). That is the direct result of a 2006 policy of the MDEIE (Ministère du développement économique, de l'innovation et de l'exportation du Québec), which put forward as a priority the inclusion of SMEs in the consortium (CANADA, 2006). All SMEs interviewed by the authors of this paper have highlighted the importance of CRIAQ in their respective innovation processes; two of them stated that CRIAQ is the only collaborative R\&D front on which these companies are engaged.

As for the number of projects, at the end of 2010 CRIAQ has 58 active projects (either in progress or in the preparation phase) and 21 closed projects, distributed in four project rounds and international agreements, not to mention the 48 potential projects that resulted from CRIAQ's $5^{\text {th }}$ research forum that took place in 2010 (CRIAQ, 2010). The rising 
number of members and projects are undoubtedly indicators of the acceptance of the model from both companies and STIs.

\subsection{Scope and organization of the consortium}

CRIAQ aims to be an interface between universities, research centers and companies. Bazergui (2007) proposes a way to understand CRIAQ's positioning through the "innovation triangle", reproduced in Figure 2. The idea behind this triangle is to map how different agents are placed in relation to the trinomial "knowledge-technologyproduct", that is, the intensity of the participation of a particular agent in the generation of each one of these factors. For instance, firms are more likely to be closer to the "product" vertex, while universities are closer to the "knowledge" vertex and research centers strive to place themselves equidistantly from all three vertices. As illustrated in Figure 2, CRIAQ aims to position itself exactly in those activities that are common to companies, universities and research centers (FORTIN, 2010).

The ordinary mechanism for the generation of research projects is a workshop called "research forum", organized by the consortium board every two years (FORTIN, 2010). All local companies in the aerospace value chain are welcome to join the forum, regardless of whether
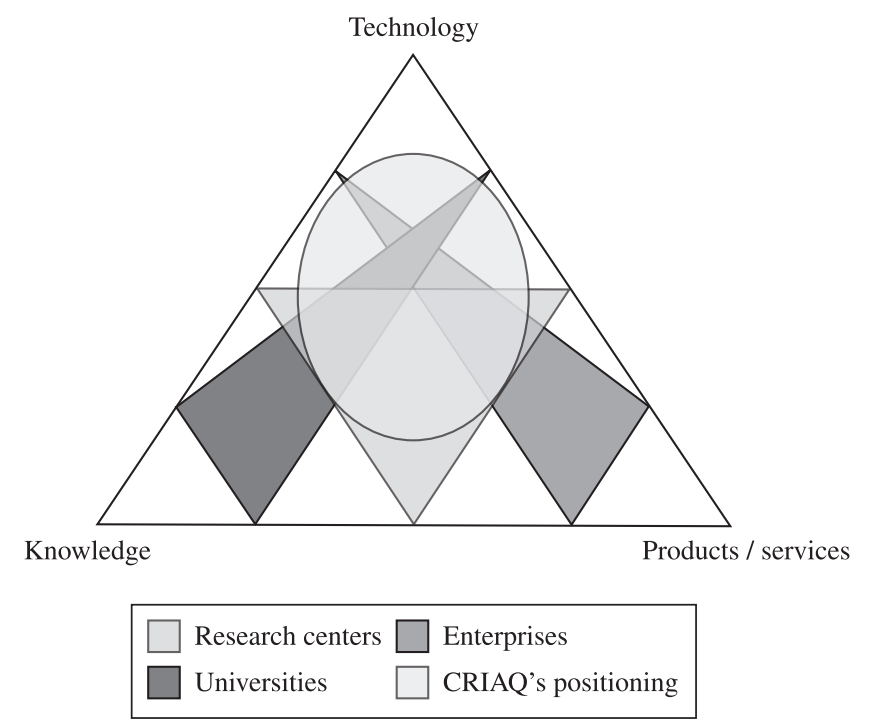

Figure 2. CRIAQ positioning. Fonte: adapted from Bazergui (2007). they already are CRIAQ members or not. All participants are encouraged to share their technology needs, which are discussed and analyzed. From the discussion, project opportunities are raised and formulated for later discussion in specific committees formed by parties interested in the project. For the opportunities in which there is viability, relevance and interest, research projects are formulated. All research projects formulated within the forum are included in its executive summary. The next steps for the project launch are the submission to the NSERC (Natural Sciences and Engineering Research Council of Canada) and, upon approval of the project by the latter, the signature of a cooperation agreement by all participating entities (FORTIN, 2010).

For general information about the extent of participation to these events, Table 2 presents the numbers of participants and projects of the last three forums organized by the board; given that, according to the MDEIE (CANADA, 2010), the official number of aerospace companies in Quebec is 240, it is evident that the substantial industry participation in these forums is what partly explains their success.

The collaboration structure for financing projects follows the scheme illustrated in Figure 3. According to this scheme, one observes that CRIAQ acts as the intermediary among all agents in the funding process.

All funding originated from Provincial sources and the counterpart given by participating companies is paid to the consortium, which in turn distributes it to the project teams. Besides those resources, the universities generally count on other grants, including those from federal sources, which are applicable to the research projects of the consortium. Projects are headed by university staff, which may include professors, post-doc researchers, graduate and undergraduate students (BAZERGUI, 2007).

It's worth mentioning that in order to be part of the Consortium, a project requires at least two interested companies and two universities involved (BAZERGUI, 2007). This rule's purpose is to guarantee that CRIAQ's projects are of more general interest to the industrial sector, and do not aim solely at solving specific problems of a particular company (FORTIN, 2010).

As previously mentioned, all CRIAQ projects are aimed at pre-competitive technologies. Speaking in terms of TRL (technology readiness levels), as defined by Mankins (1995), CRIAQ's projects are often classified between TRL 2 and 5 (FORTIN, 2010), which means that typical projects

Table 2. Participation and results from the last forums.

\begin{tabular}{|l|c|c|c|}
\hline \multicolumn{1}{|c|}{ Forum } & $\mathbf{3}^{\text {rd }}$ forum (2006) & $\mathbf{4}^{\text {th }}$ forum (2008) & $\mathbf{5}^{\text {th }}$ forum $(\mathbf{2 0 1 0})$ \\
\hline Participants from industry (enterprises represented) & $225(90)$ & $290(100)$ & $395(142)$ \\
\hline Projects & 14 new projects & 34 new projects & 48 potential projects \\
\hline
\end{tabular}

Source: adapted from CRIAQ (2010). 


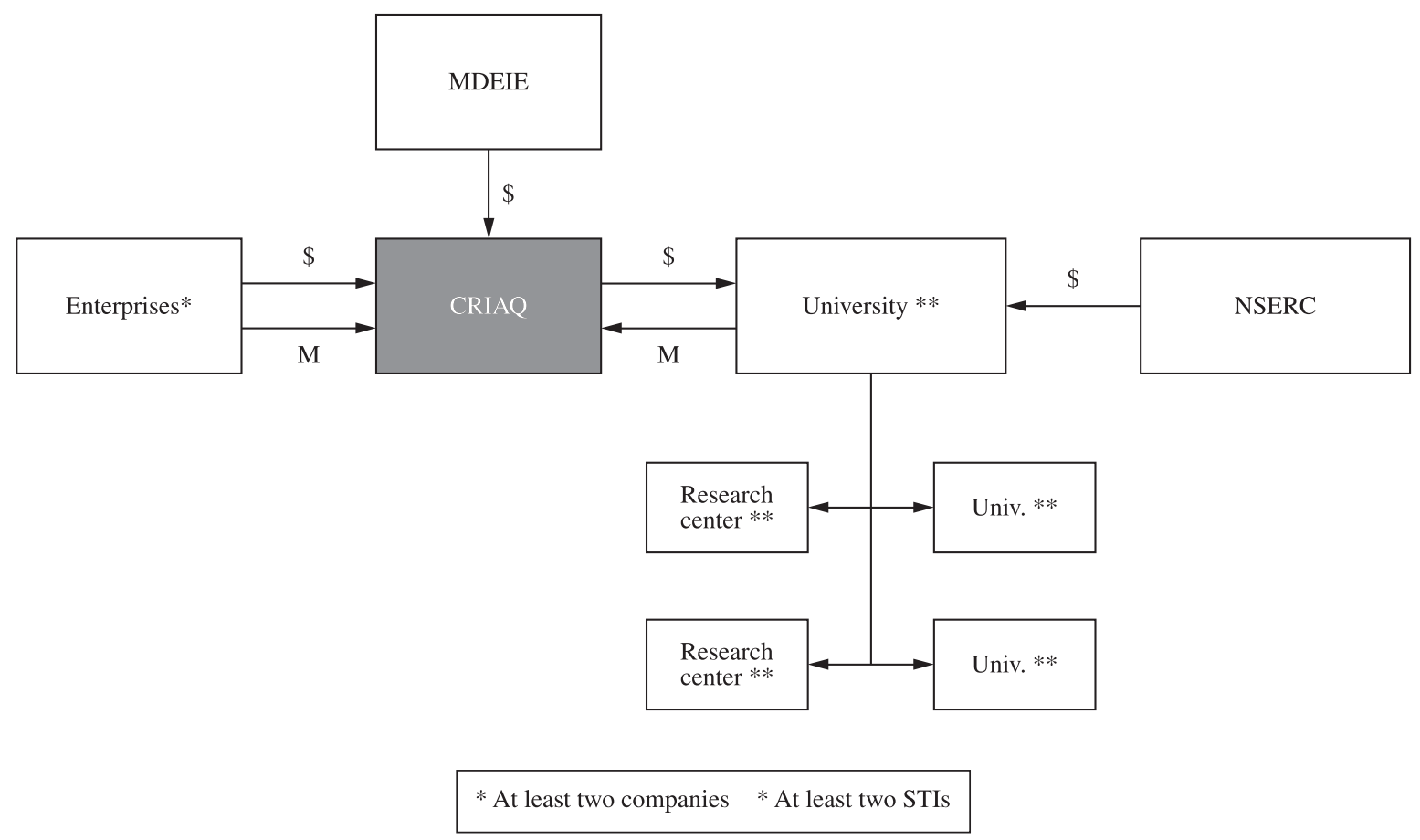

Figure 3. Project financing. Source: adapted from Fortin (2010).

lie between research for conceptualization and formulation of insipient technologies (TRL 2) and component or subsystem validation in a relevant environment (TRL 5). The reason for focusing on pre-competitive technologies is that this is the stage of maturity in which companies are eager to collaborate with others (even competitors) in order to reduce innovation costs, and are not too worried about secrecy issues.

Research themes are created as forums identify that CRIAQ members have an interest for research in a specific area, associated with the capacity (and interest) in researching the topic by local universities. At the end of 2010, CRIAQ thematic fields were those listed in Table 3.

The firm's role is to follow up projects in which they are involved, by participating in follow-up and technical meetings and, in some cases, by transfering technologies and proprietary know-how required to the executive teams (FORTIN, 2010).

One of the main reasons for the success of the consortium is its structure for intellectual property (IP) management, which ensures a secure environment for information exchange provided by clear agreements of collaboration and participation. By default, all knowledge and technologies eventually generated by the projects are the property of the university that executes the project, with an exclusive right of exploitation by the companies participating in the project (FORTIN, 2010).

Finally, another type of collaboration that has been adopted by CRIAQ since 2007 is that of international
Table 3. CRIAQ research themes.

\begin{tabular}{|c|c|}
\hline Acronym & Theme \\
\hline ACOU & Vibro-acoustics and noise control \\
\hline AVIO & Avionics and control \\
\hline COMP & Composites \\
\hline DPHM & $\begin{array}{l}\text { Diagnostics, prognostics, health monitoring and non } \\
\text { destructive testing (NDT) }\end{array}$ \\
\hline ENV & Icing, safety, environment \\
\hline INTD & Interior design \\
\hline LEAN & Optimization and lean \\
\hline MANU & Manufacturing \\
\hline MDO & $\begin{array}{c}\text { Modeling, simulation, optimization, system } \\
\text { integration }\end{array}$ \\
\hline PLM & Product life cycle management \\
\hline SPLY & Supply chain \\
\hline
\end{tabular}

Source: adapted from Fortin (2010).

collaboration, which follows the framework presented in Figure 4 (BAZERGUI, 2007). For the establishment of an international collaboration project, there must be a previous partnership between the companies, a Quebec resident company and a foreign one, both interested in the research project, as well as universities and funding agencies in both countries (FORTIN, 2010).

CRIAQ's role in this case is to serve as an intermediary for the local players only. The division of scope between countries is determined by the companies. Depending on that division, the interaction between local and foreign 


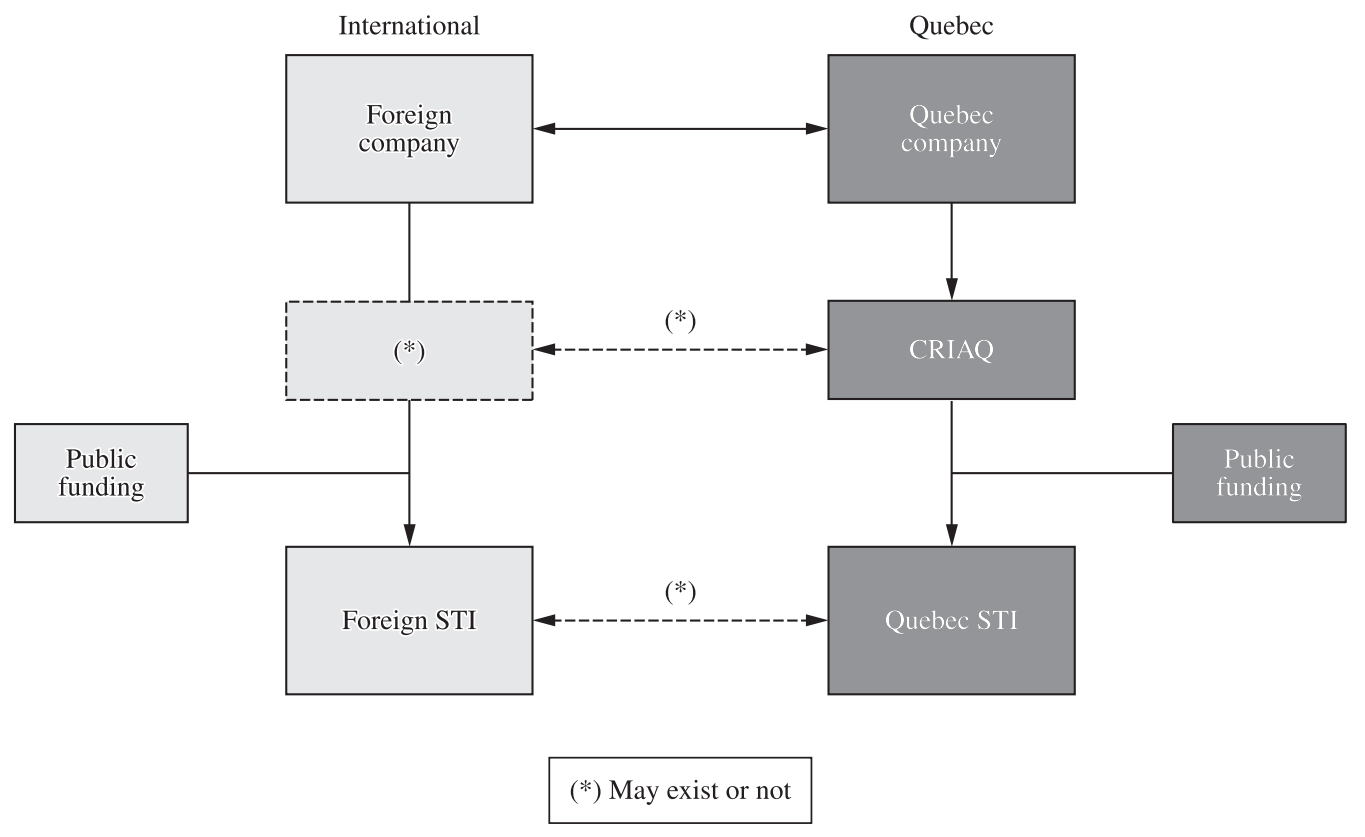

Figure 4. Framework for international collaboration. Source: adapted from Bazergui (2007).

universities may be required or not. The management and funding models adopted by CRIAQ for this kind of collaboration is the same as for all other research projects of the consortium, and is limited to local activities.

At the end of 2010, CRIAQ had seven active international collaboration projects, all of which with India, and other four projects in planning stages with India, China, France and Germany (CRIAQ, 2010).

This is, in brief, the modus operandi of the Consortium for research and innovation in aerospace in Quebec.

\subsection{Critical analysis of the consortium}

Analyzing the elements described in the previous section, adding up the impressions from conversations that the authors held with academy and industry professionals engaged in projects of the consortium, the following factors are thought to have contributed to CRIAQ's success:

- The initiative for creating the consortium came from the academy, and the consortium also finds good receptivity by local universities and research centers that see in the consortium an opportunity to offer their students and researchers high-quality research with real application and industrial interest, at the same time that it contributes for the universities' primary mission of forming high-quality professionals for the industry;

- The consortium counts on the interest of virtually all the great players of the local industry, including all four prime contractors, which goes beyond simple institutional support, but includes funding and, in some cases, technology transfer to executing teams;
- The involvement of SMEs contributes to a significant increase in the dynamics of projects, because SMEs are eager to collaborate. CRIAQ represents for these types of firms a unique opportunity to create a closer relationship with big companies in the sector, to make their own expertise and technical capabilities known, to reach university scholars at a relatively low cost and to develop joint technologies that may be incorporated in the future to the global products of the big companies involved;

- Governmental and funding support is not limited to companies with Canadian ownership only, but is extended to all resident companies that perform R\&D in Quebec. It constitutes an incentive for foreign companies to take this kind of activities to the Province, and contributes for the creation of a regional innovation ecosystem whose benefits exceed the direct gains to the projects themselves, due to the spillovers generated;

- CRIAQ's strong IP protection structure provides guarantees and security for all participants of the consortium;

- The rotating and mixed composition of the board of directors of the consortium provides transparency to CRIAQ activities as a whole, and makes it difficult for decisions to favor a particular company over more general interests of the local industry segment;

- The very focus of the consortium in pre-competitive technologies also constitutes an advantage to the framework because, as previously mentioned, it is a level of technology maturity within which companies 
feel comfortable to collaborate, as they often do not involve industrial secrecy. At the same time, on the behalf of the academy, this kind of research is well regarded by scholars in general, once it converges with the university mission of training and knowledge generation;

- The research forum as a tool for the generation of ideas and the formulation of research projects is a unique opportunity for discussion and definition of technology challenges of the aerospace industry as a whole. Additionally, the high participation of industry players in these forums is a decisive factor for their success.

Turning now to the negative aspects of the consortium, one can highlight the following:

- Since CRIAQ is an initiative of the Province of Quebec, and due to the history of antagonism between this Province and the rest of Canada, an inherent difficulty of the consortium is to expand its network outside the borders of Quebec, although there are currently cases where this barrier has been transposed;

- In order to be part of the consortium, a company is required to have formed an R\&D structure $a$ priori. It is not part of CRIAQ's scope to aid SMEs in this organization, in case the company lacks an R\&D structure. This factor prevents a higher accession of SMEs in the consortium, on the one hand, but guarantees that all participating members be familiar with $R \& D$ activities, which enables them to positively contribute to the generation of knowledge and value capture from research projects conducted by the consortium;

- The mentors of CRIAQ have still not found a business model that could make viable research projects of more mature technologies (besides pre-competitive ones), although this is a future ambition of the consortium (FORTIN, 2010);

- The same problem exists for the viability of industryindustry collaboration projects, which is also a desire of CRIAQ (FORTIN, 2010).

\section{Innovation context in the Brazilian aerospace sector}

The regulatory mark for innovation in Brazil is the federal law 10,973/04 (BRASIL, 2004), known as "the innovation law", which provides a legal basis for the establishment of effective policies of government-university-enterprise collaboration (the triple helix). However, as it is a recent law, it is still in process of maturation and assimilation by all three agents.

On behalf of the government, since the promulgation of the law, many initiatives have been launched to promote innovation in the country (CGEE, 2008). Among them, it is worth mentioning the various granting and funding programs sponsored by governmental agencies FINEP (Financiadora de Estudos e Projetos) and BNDES (Banco Nacional do Desenvolvimento), and the promulgation of federal law 11.196/05 (BRASIL, 2005), which includes a number of tax credits incentives for companies that perform innovative $\mathrm{R} \& \mathrm{D}$ activities. Many of these incentives and programs are applicable for the aerospace market, since this is an industrial segment that is regarded as strategic by the federal government (ABDI, 2009).

On the side of the universities, in an OECD working paper from Brito Cruz and Mello (2006) that presents the Brazilian NSI, one observes the increasing numbers of publications and impact in Brazilian research. Additionally, the number of researchers and graduate programs is also increasing. This general tendency in the Brazilian academy is also true for aerospace research, which counts on important research and higher education institutes for the segment, such as CTA (Centro Técnico Aeroespacial), ITA (Instituto Tecnológico da Aeronáutica) and INPE (Instituto Nacional de Pesquisa Espacial), all of them located in the aerospace technological pole in São José dos Campos, which constitutes important vectors for knowledge generation.

The problem that Brito Cruz and Mello (2006) point out in Brazilian NSI is the distortion of the country in relation to regular standards in developed and developing countries in terms of the percentage of the research performed in the industry: in Brazil, only $26 \%$ of researchers work in private enterprises, while in most developed and developing countries, this percentage is of about $80 \%$.

Specifically regarding the aerospace sector, it is a oneof-a-kind segment in Brazil, since it is the only high-tech sector in which the country has an outstanding performance in the global market, mostly due to the performance of Embraer, one of the global leaders in the regional jets market (FERREIRA, 2009). Nevertheless, Brazilian aerospace industry is heavily dependent of foreign technology, even Embraer: when analyzing this company's supply chain, one observes that about $93 \%$ of its suppliers are located abroad (FIGUEIREDO; SILVEIRA; SBRAGIA, 2008). That does not mean that Embraer is not engaged in $R \& D$, nor that this company is not worried about the development of precompetitive technologies, but that it is done through strong collaborative links established with Embraer risk-sharing partners, which are in general foreign (RESENDE, 2008).

In the rest of the industry, what one observes is that it is a highly segmented industry, constituted mostly by small and medium enterprises that act in niche markets (FERREIRA, 2009). Due to their size, they are typically companies that do not have self-sufficiency in terms of R\&D. In both cases, the result is that the internal $R \& D$ structure of the companies in the segment is deficient.

However, according to Chesbrough (2003), in order for a company to profit from an open innovation environment, 
as the one provided by a university-enterprise collaborative consortium such as CRIAQ, a solid internal R\&D structure is necessary in order to enable the company to capture part of the value created in such environment. This deficiency seems to be the main obstacle for the viability of the implementation of a collaboration framework such as CRIAQ's in Brazil.

\section{Conclusions and implications of the study}

This paper presents CRIAQ as a successful framework for university-enterprise collaboration with governmental support and funding, as advocated by the triple helix theory.

CRIAQ's dynamics and focus is attractive for companies and does not contradict the university's mission of forming people and generating knowledge. This is currently obtained by the focus on pre-competitive technology research projects in a partnership model of at least two companies and two universities involved under the coordination of CRIAQ's board.

It is important to stress that one of the main reasons for the success of the consortium is that its members have a correct attitude regarding the knowledge created in the university: academic knowledge is not something susceptible to "capitalization" of "privatization", according to Freeman's critique about the way companies are normally tempted to see universities (LASTRES; CASSIOLATO; ARROIO, 2005). The academic scholar cannot be regarded simply as a lower cost alternative for the internal R\&D of a company, but as a different source that produces a different kind of output: a less mature knowledge in terms of its application in products and processes, but that can serve as a basis for innovation in the medium and long terms.

Analyzing Brazilian NSI, and particularly the case of the local aerospace industry, the main obstacle for establishing a similar model is the lack of internal $R \& D$ in Brazilian companies of the sector, as academic potential and governmental engagement do not seem to be the problem. Without an internal structure that enables value capture on behalf of the companies, there is no possibility of entrepreneurial interest in a consortium such as CRIAQ in the Brazilian industry.

As suggestion for future studies on the subject, one could analyze alternatives for solving this deficiency to raise interest in local companies in a collaboration framework similar to CRIAQ's. After that, it is worth analyzing what adaptations would be required for creating an adequate proposal of a consortium that suits the Brazilian reality, because, as Lastres, Cassiolato and Arroio (2005, p. 27) observe:

[...] there is not a unique solution or recipe for policies, but a multiplicity of alternatives that may assume different forms for different societies in different places and moments.

\section{Acknowledgements}

The authors wish to thank CRIAQ, in the person of Pr. Clément Fortin, president of the consortium in the 2010-11 administration, for presenting the object of study of this paper, for sharing detailed information on the subject, and for the support on the research project as a whole.

The authors also thank the Ministère de l'Éducation, du Loisir et du Sport du Québec (MELS) and the Coordenação de Aperfeiçoamento de Pessoal de Nível Superior do Brasil (CAPES) for financial support by granting scholarships to the research project to which this paper belongs.

\section{References}

AGÊNCIA BRASILEIRA DE DESENVOLVIMENTO INDUSTRIAL - ABDI. Estudo prospectivo aeronáutico: relatório geral. Centro de Gestão e Estudos Estratégicos, 2009. (Série Cadernos da indústria ABDI, v. 14).

ANDERSEN, E. National innovation systems in the context of multi-sectoral growth and development. DRUID Summer Conference on Innovation Systems, 1999. Available from: <http://www.druid.dk/conferences/summer1999/ conf-papers/ESAndersen.pdf>. Access in:16 may 2011.

BAZERGUI, A. CRIAQ, a Winning Model for Industryled Collaborative Research in Aerospace, and its Role within Aéro Montréal. In: FORUM INNOVATION AÉROSPATIAle, 2007, Montréal. Proceedings... CRIAQ, 2007. Available from: <http://www.aeromontreal. ca>. Access in: 24 nov. 2010.

BRASIL. Lei $n^{\circ} 10.973$, de 2 de dezembro de 2004. Dispõe sobre incentivos à inovação e à pesquisa científica e tecnológica no ambiente produtivo e dá outras providências. Diário Oficial da República Federativa do Brasil, 3 dez. 2004. Available from: <http://www.planalto.gov.br/ ccivil_03/_ato2004-2006/2004/Lei/L10.973.htm>. Access in: 19 may 2008.

BRASIL. Lei $\mathrm{n}^{\circ}$ 11.196, de 21 de novembro de 2005. Institui o Regime Especial de Tributação para a Plataforma de Exportação de Serviços de Tecnologia da Informação - REPES. Diário Oficial da RepúblicaFederativa do Brasil, 22 nov. 2005. Available from: <http://www.planalto. gov.br/ccivil_03/_Ato2004-2006/2005/Lei/L11196.htm>. Access in: 19 may 2008.

BRITO CRUZ, C. H.; MELLO, L. Boosting innovation performance in Brazil. Organisation for Economic Cooperation and Development, Economics Department, 2006. Working Paper, n. 532.

CANADA. Ministère du Développement économique, de l'Innovation et de l'Exportation du Québec - MDEIE. Stratégie de développement de l'industrie aéronautique québécoise. Québec: MDEIE, 2006. Available from: <http:// 
www.criaq.aero/Donnees/2006_MDEIE_Strategie.pdf $>$. Access in: 14 oct. 2010 .

CANADA. Ministère du Développement économique, de l'Innovation et de l'Exportation du Québec - MDEIE. Présentation de l'industrie aérospatiale. Québec: MDEIE, 2010. Available from: <http://www.mdeie.gouv. qc.ca/index.php?id=2284>. Access in: 2010/11/11.

CENTRO DE GESTÃO E ESTUDOS ESTRATÉGICOS CGEE. Os novos instrumentos de apoio à inovação: uma avaliação inicial. CGEE, 2008. Available from: <www.cgee. org.br/atividades/redirect.php?idProduto=5613>. Access in: 21 aug. 2009.

CHESBROUGH, H.W. Open innovation: the new imperative for creating and profiting from technology. Harvard Business School Press, 2003.

CONSORTIUM DE RECHERCHE ET D'INNOVATION EN AÉROSPATIALE AU QUÉBEC - CRIAQ. Dépliant du CRIAQ. CRIAQ, 2010. Available from: <http://www. criaq.aero/Presentation/100527_depliant_fr.pdf $>$. Access in: 10 may 2011.

DAHLANDER, L.; GANN, D. M. How open is innovation? Research Policy, v. 39, p. 699-709, 2010. http://dx.doi. org/10.1016/j.respol.2010.01.013

DE JONG, J. P. J. et al. Policies for open innovation: theory, framework and cases. VISION Era-Net, 2008. Available from: <http://www.openinnovation.eu/download/ OIPAFfinalreport.pdf>. Access in: 17 nov. 2008.

DOSI, G. et al. (Eds.). Technical Change and Economic Theory. Pinter Publishers, 1988.

FERREIRA, M.J.B. Perspectivas do investimento em ciência - documento setorial: aeroespacial \& defesa. Universidade Federal do Rio de Janeiro, Universidade de Campinas, 2009. v. 12. Projeto PIB. Available from: <http://www.projetopib. org/arquivos/12_ds_ciencia_aeroespacial_defesa.pdf $>$. Access in: 04 nov. 2011.

FIGUEIREDO, P.; SILVEIRA, G.; SBRAGIA, R. Risk sharing partnerships with suppliers: the case of Embraer. Journal of Technology Management and Innovation, v. 3, n. 1, p. 27-27, 2008.

FORTIN, C. Presentation du consortium de recherche et d'innovation en aérospatiale au Québec. In: FORUM DES ÉTUDIANTS EN AÉROSPATIALE - FEA 2010, 2010, Montréal. Proceedings... École Polytechnique de Montréal, 2010.

FREEMAN, C. Technology policy and economic performance - lessons from Japan. Pinter Publishers, 1987.

FREEMAN, C. Japan: a new national system of innovation. In: DOSI, G. et al. Technical Change and economics. London: Pinter Publishers, 1988. p. 330-48.
FREEMAN, C. The 'National System of Innovation' in historical perspective. Cambridge Journal of Economics, v. 19, p. 5-24, 1995.

HUIZINGH, E. K. R. E. Open innovation: State of the art and future perspectives. Technovation, v. 31, n. 1, p. 2-9, 2011. http://dx.doi.org/10.1016/j.technovation.2010.10.002

LASTRES, H. M. M.; CASSIOLATO, J. E.;ARROIO, A. (Orgs.). Conhecimento, sistemas de inovação e desenvolvimento. Editora UFRJ, Contraponto, 2005.

LUNDVALL, B. A. (Ed.). Product innovation and userproducer interaction. Aalborg University Press, 1985. (Industrial Development Research Series, n. 31).

LUNDVALL, B. Å. (Ed.). National innovation systems: towards a theory of innovation and interactive learning. Pinter Publishers; 1992.

MANKINS, J. C. Technology readiness levels: a white paper. NASA, 1995. Available from: <//www.hq.nasa.gov/office/ codeq/trl/trl.pdf>. Access in: 08 nov. 2010.

NELSON, R. R. Institutions supporting technical change in the United States. In: DOSI, G. et al. Technical Change and economics. London: Pinter Publishers, 1988. p. 312-29.

NELSON, R. R. (Ed.). National Innovation Systems: A Comparative Analysis.Oxford University Press, 1993.

ORGANIZATION FOR ECONOMIC CO-OPERATION AND DEVELOPMENT - OECD. National innovation systems. OECD, 1997. Available from: <www.oecd.org/ dataoecd/35/56/2101733.pdf>. Access in: 07 oct. 2010.

ORGANIZATION FOR ECONOMIC CO-OPERATION AND DEVELOPMENT - OECD. Open innovation in global networks. OECD, 2008.

RESENDE, H. B. Embraer: building a globally competitive company. In: OPEN INNOVATION SEMINAR BRAZIL, 2008, São Paulo. Anais...São Paulo, 2008. Available from: <http://www.slideshare.net/Allagi/openinnovation-seminar-2008-mesa-1-hugo-resende-embraer>. Access in:07 jan. 2011.

SÁBATO, J. A.; BOTANA, N. La ciencia y la tecnología em el desarrollo futuro de América Latina. Revista de La Integración, v.1, n.3, p. 15-36, 1968.

WONG, P. K. (1999) National Innovation Systems for Rapid Technological Catch-up: Ananalytical framework and a comparative analysis of Korea, Taiwan and Singapore. In: SUMMER CONFERENCE ON NATIONAL INNOVATION SYSTEMS, 1999. Proceedings... DRUID, 1999. Available from: <http://www.druid.dk/conferences/summer1999/ conf-papers/wong.pdf>. Access in: 16 may 2011. 
